KRZYSZTOF UNIŁOWSKI

Translated by: JAKOB ZIGURAS

Translation viewed by: PAWE K KACZMARSKI

Textualism, Materialism, Immersion, Interpretation

\title{
A note from the editors
}

Krzysztof Uniłowski passed away earlier this December. For the last twenty years, he has been crucial to Polish literary studies. Writing on a broad range of topics - from reviews of contemporary Polish novels to essays on the idea of modernity, from class-oriented analyses of sci-fi books and TV shows to comments on the politics and ethics of literary criticism - he developed an impressive and highly unique critical perspective, or indeed: a unique language of criticism, one that has managed and will undoubtedly still manage to inspire countless critics of all generations. Throughout his work, Uniłowski drew heavily on historical materialism, constantly balancing his instinctive focus on the political - and, specifically, on class - with his equally instinctive conviction as to the irreplaceability of literary form. While we might not have agreed on every single issue - as is always the case on the Left - we in "Praktyka Teoretyczna" are proud to have called him not just an inspiration, but a comrade.

Uniłowski passed away while putting finishing touches to the essay we're presenting below. Unfortunately, he never managed to send us the finished abstract/summary for this article, so it falls to us to try and summarise its main theses. 
The issues raised in this erudite and formally complex piece include such fundamental questions as: in what sense do the fictional worlds resemble the non-fictional one, and how do we inhabit them? What's the relationship between immersion and interpretation? What real-life figures can help us imagine or visualise our intimate yet inherently social relationship with the fictional (are we guests, dwellers, passersby...)? Uniłowski looks for answers in contemporary Marxist criticism (Eagleton, Jameson, Berardi), sci-fi and fantasy writing (Lem, Sapkowski, Martin), as well as modern continental philosophy (Gadamer, Heidegger) and - in the last part of the essay - contemporary game studies.

We're happy to be able to present Uniłowski's piece in two versions, the original Polish as well as its English translation (by Jakob Ziguras). In order to preserve the unmistakable flow of Uniłowski's thought in English, small changes were introduced - with the author's full approval - in the English version. We trust that our Polish-speaking readers will find the comparison of the two versions interesting and instructive, as they seem to give a unique insight into Uniłowski's writing process.

Keywords: textualism, materialism, immersion, interpretation, utopia 
Around 2000, many attempts were made to revise the textual paradigm that had dominated the humanities since the 1970s. These efforts have had (and have) an important political profile. Referring to the great criticism of postmodernism carried out by, among others, Fredric Jameson (1991) or Terry Eagleton (Eagleton 1996), it was eagerly emphasized that postmodern textualism belongs to the rules of late capitalist, neoliberal economics. ${ }^{1}$ Hence, the attempts to recover all that was lost in the postmodern circulation of signs: the body (also the social body), sexuality, sensual experience, etc. The generational aspect also seems to be important here. New theoretical projects aroused particular interest among young scholars in the humanities, wishing to stand apart from the generation of their postmodern "fathers".

I provide some reflections on such concepts as new materialism or immersion. Their popularity shows the ambition to go beyond the limits of textualism, but one can doubt whether all these efforts allow us to achieve the intended goal. Finally, the body, the social body, sexuality, sensual experience-all this is subject to interpretation, which leads us back to textuality.

The death of the author was supposed to serve the interpretative freedom of the reader. It placed him, however, against an impenetrable textual machinery, whose "sense-producing work" realised itself as if beyond every economy and teleology. The new understanding of the text constituted - at least in intention - a form of negation of the capitalist system. It marked out a sphere of production not subject to the categories of profit or, more broadly, of exchange value. For this reason, one should value the emancipatory and utopian potential of this conception; yet, on the other hand, the text as a process in which "languages circulate" unceasingly (Barthes 1977:164), may, equally well, be treated as an automaton, constituting an aesthetic representation of capitalism and semiocapitalism.

In relation to such a text, we find ourselves in a position similar to that of the protagonists of Stanisław Lem's Eden, who, having penetrated a foreign planet, come across something that seems to be a massive factory. One of them describes it thus:

1 The book by Bartosz Kuźniarz (2011) should be mentioned here from the Polish humanities literature.

The death of the author was supposed to serve the interpretative freedom of the reader. It placed him, however, against an impenetrable textual machinery, whose "sense-producing work" realised itself as if beyond every economy and teleology. The new understanding of the text constituted-at least in intention-a form of negation of the capitalist system. 
The Doctor smiled. "These things are drawn in here" - he pointed to the snout, which just then happened to open. "Now it's warming up inside, see? And now they're melting, fusing, being carried to the top in portions, where they're treated. Then, still red-hot, they drop to the bottom, underground - there must be another level there - and something else happens to them, and they come back up, by the same well, pale but still glowing. They journey up to the ceiling, fall into this" - he indicated the funnel - "and from there go into the trough, then the snout, melt, and so on and so on, forming, melting, forming” (Lem 1990: 50).

The very description of the thing in question as a "factory" is offered — how could it be otherwise-by the Engineer ("Well, we're home at last — this is a factory, an automated factory!" — Lem 1990: 46) and, in accordance with the principle of the Adamic name, is consistently exploited by the protagonists in their attempts to describe and cognitively master the object. Nevertheless, Lem's third-person narrative also introduces a few other tropes, transforming the object into a space —relating it now to a forest ("they wandered through the pulsing forest of this unusual factory" - Lem 1990: 47), now to an underground labyrinth ("the labyrinth on tubes" - Lem 1990: 49)—and, above all, it makes use of descriptions that animate the "factory" and ascribe to it the characteristics of a massive monster, a leviathan, in the bowels of which the astronaut-researchers have found themselves. If the Engineer's first identification domesticated this space ("we're home"), now-in accordance with the progress of the protagonist's journey - the space undergoes a de-realisation, being transformed, according to the logic of a nightmare, into a symbolic zone of danger and trial (a fairy-tale forest), metaphysical and existential riddle (a mythical labyrinth) and eschatological passage (the biblical Leviathan). The oneiric character of this fragment of the story is underlined by the fluid border between third-person narration and the protagonists' own speech; for instance, metaphorical descriptions pass from the text of the story into the independent speech of the characters. As an example, the "snout" appears first on the part of the narrator, and is next referred to with the pronoun "it" by the Doctor. We have, thus, an uncommon situation, where the narrator's descriptions qualify the seemingly independent speech of the characters. At the same time, the discourse implied by the original identification and the first name ("factory"), loses credibility and is now used as a mere quotation, thus underlining its own conventional character.

The metaphoricity and oneiric lability of the space sets into motion a process of cognitive dispossession of the protagonists; while the unen- 
ding and impalpable circulation - the product is transformed seamlessly into waste, and this in turn into raw material - appears to be marked by madness. Production directed at itself, deprived of an external goal or sense, turns out to be a production of a sort that does not manufacture anything apart from the production of production itself. But, at the same time, the mechanism of repetition that propels the circulation, is based as much on self-presentation as on doubling — in consequence of which we're faced with production multiplying itself without end, obsessed with itself. The unreal space of absolute otherness, which there is no way to describe adequately, seems to come to life, to acquire monstrous characteristics, consuming the unfortunate researchers. The danger stems from the fact that the protagonists do not now stand face to face with the unknown, but rather are caught in the trap of language itself. However, if the "factory" discovered by them is a form of madness, then this must be their own madness, or at least the madness of the Doctor (from this perspective, his strange smile would be a symptom of the madness of the protagonist himself). ",Have you gone mad?" whispered the Engineer. On his forehead were large drops of sweat" (Lem 1990: 51). Except that both the whisper (not a shout) and the "large drops of sweat" suggest that he also suspects himself of participation in this madness.

In just this sense, the scene in the putative factory-from the story by Stanisław Lem - would constitute a critique of modernity; whereas the threat of madness would pertain precisely to the modern subject, who discovers that he has been dispossessed of his own language. However, another reading is possible, which would see the same scene transformed into a prefiguration of the late-capitalist simulation of desire. Referring to Deleuze and Guattari, Manfred Geier suggested that the "factory" functions in Lem's novel like a schizophrenic desiring machine, being a source not only of cognitive confusion, but also of . . pleasure:

All of this together, necessarily maintained in the shoddy order of a master concept: the "factory", (. . .) "functions" as a game, as a process of linguistic production, which may be - and desires to be — read without subordination to the laws of an in-advance-agreed-upon and socially -determined significativeness (Geier 1989: 118-119, my italics).

Nevertheless, such a change of perspective would demand one thing, namely: the abandonment of the question of meaning and the inclusion of oneself into this "game," going as far as the self-destruction of the subject in an ecstasy of "linguistic production." Of course, the pleasure

The scene in the putative factory-from the story by Stanisław Lem-would constitute a critique of modernity; whereas the threat of madness would pertain precisely to the modern subject, who discovers that he has been dispossessed of his own language. 
flowing from this would demand a certain price. This time, however, the subject would be subject to being dispossessed not of language, but of matter, to being transfigured from a bodily being into a being purely communicative. The promise, which the textual automaton makes to us, has to do not only with plaisir du texte, but also - être sauvée par texte.

Not long after the year 2000, in feminist theory, there arose the need to oppose oneself to the textualism that had, until recently, been influential. As Katarzyna Szopa explains, "the stranglehold of postmodernist constructivism, 'backfired' after such events as terrorist attacks, cataclysms, the development of late capitalism, wars, the degradation of the environment etc." (Szopa 2018: 99) Yet if we move beyond declarations, it will turn out that the shift away from textualism is not an easy matter, and the transition to the new materialism is founded upon a chain of substitutions. Szopa, the author of a monograph on Luce Irigaray, emphatically underlines that, already in the 1980's, there arose, with regard to this issue, a certain misunderstanding - as a result of which, Irigaray's pre-"new materialist" position was occasionally criticized, at the time, as being a hidden essentialism. On the other hand, it seems that feminist materialism itself, despite everything, remained in a certain relation with essentialism:

According to [Alison] Stone, such an understanding —of biology, essence and matter as self-forming substances, taking an active part in the production of meaning-is fundamentally an essentialist standpoint. This is because it assumes that matter possesses a pre-discursive or pre-cultural essence, which is active, causative and dynamically changing, as well as tending to the expression of its specificity at the level of form and cultural activity. Contemporary scholars of feminism described this position by the term "new materialism" (Szopa 2018: 91, italics mine).

Nevertheless, already in the next sentence, Szopa states unambiguously: "Materialism, in Irigaray's work, is a perspective that is erroneously identified with essentialism" (Szopa 2018: 91). Thus, perhaps Alison Stone simply repeats the old mistake; though one could also express this more carefully, by assuming that all she did was recapitulate some of the existing accusations (Stone 2006; cf. Szopa 2018: 18). In any case, 
Katarzyna Szopa calls, as her next witness, Naomi Schor, according to whom the "pre-discursive exteriority" in Irigaray's work is not bound up with an absolutization of the idea of the biological body, but rather indicates a particular referential sphere, one that's of concern to the experimental sciences. Nevertheless, the quote below shows emphatically that the experimental sciences function here as an instance of authority founded upon an immediate act of faith. We read:

And that is her [Irigaray's - K.U.] reliance on the universe of science, notably physics (but also chemistry to the extent that the borders between them cannot always be clearly drawn) which enjoys a strange and largely unexamined privilege in Irigaray's conceptual universe (Schor 1994: 53).

So, if the scientific domain constitutes a privileged (originary) plane of reference for the practice of re-semanticisation, in Irigaray's philosophy, of the female body - or, specifically, of its generative parts, above all the "two lips" as well as the placenta - then it is clear that her "materialist" approach could be reduced to a merely discursive operation, as it consists solely in an invocation of a particular "scientific" language, the choice of which remains arbitrary and thus beyond any rational justification. As a result, the very privileging of science is seen by Schor as a spectacle of the uncanny, because precisely the category of the "uncanny" is evoked by the description of it as "strange" as well as "largely unexamined". Thus, the reference to science clarifies nothing, but rather to the contrary — additionally “obscures" Irigaray's arguments.

It follows from this that the gender difference does not at all have a pre-established character; to the contrary-it is established precisely through the sense-producing process; while its alleged "irreducibility" constitutes, in essence, a proposal—the assumed "finished product" that's presupposed by the entire operation. The joke lies in the fact that this "finished product" remains a regulative idea which, in the course of discursive practice, is invoked and mediated exclusively in a series of figurations following upon one another.

Franco Berardi's book The Uprising operates within a rhetoric of messianism, introduced here, no doubt, under the influence of Giorgio Agamben. Berardi expresses praise for a poetry that is fluidly transformed into a "coming European insurrection" (Berardi 2012: 68). Thus, poetry, 
uprising and insurrection constitute, here, a series of synonyms - not so much a passage as a series of repeated representations that reflects a series of advents, rapidly following upon one another. In this way, the predicted parousia appears as a Derridean deferral and a Barthesian "deferred action", in the context of which "the infinity of the signifier refers not to some idea of the ineffable (the unnameable signified) but to that of a playing (...)" (Barthes 1977: 158).

Berardi's project assumes that poetry enlivens equally both language and the body. The parallelism and convertibility of these formulations suggests that it is a matter of the embodiment of language, the making of it into a (bodily) organ or, equally, an instrument, an "extension," a medium of human expression. This is possible because, as one of Berardi's Polish commentators explains, "poetry assumes the presence of the voice, and thus also of the body indispensable in the process of expressing oneself" (Kłosiński 2017a: 123). Nevertheless, the passage from voice to body is made here a bit too quickly, showing signs of wishful thinking. And if Berardi states that "poetry is a singular vibration of the voice. This vibration can create resonances, and resonances may produce common space" (Berardi 2012: 147), he, at the same time, redirects attention from the source of the vibration (the voice) to the acoustic system. Let us remember, then, that resonance results not only in communication, but also in the strengthening, filtering or distortion of the vibration. In turn, the introduction into the acoustic system of electronic converters opened the way to the complete disembodiment of the voice ("For it was voice and only voice, and there was nothing else beyond!" - to quote the poem Dziewczyna [Girl] by the Polish poet, Bolesław Leśmian, writing on the brink of the age of radio). Later we even discovered that writing and text are already, in their own way, an augmentation of the voice ("Turn on your receiver" - this time, a quote from the rock band Nazareth) — one which subjects the voice to mechanisation, ultimately causing it to lose itself in a labyrinth of its own echoes and transformations.

When Michał Kłosiński employs the term "utopian alternative" to describe Berardi's project, and dismisses his demands as "banal," one can distinctly hear, in this dismissal, a note of disenchantment. A "utopian alternative" - that is, it seems, an alternative that is unreal, apparent, fictional, impossible to bring into reality . . . All this is true; nevertheless, Berardi's project should be treated not as a philosophical or theoretical statement, but — as a poetic one. Thus, the point is not that the Italian author has not come to grips with the problems towering above him, and has not presented a credible method for bringing to life the double 
miracle of the embodiment of language and of the recovery of speech. In essence, what appears as "utopian" here is not so much the specific alternative, as the materialism itself; one might say-materialismo che viene (the sequence of mediations remains after all "unendingly" open). The one thing I'm not certain about is whether materialism, as the object of eschatological desire, is truly an alternative to the capitalist "liquefaction of the world", or rather its necessary and complimentary part...

IV

Since materialism would be the utopia of our time, then all that would realistically remain for us is the textual game, unending and unlimited by anything, game as far as the eye can see. Yet, who would be the subject, the lord of this game? Already years ago, an interesting answer to this question was offered by Hans-Georg Gadamer. According to Gadamer, every game is bound up with "movement as such" (Gadamer 1989: 103) Game as movement would, of course, be a trembling; yet, in contrast to Berardi's vibration, it would not imply or point toward any mover, any source external to itself. This shift would assert "the primacy of the game over the players engaged in it" (Gadamer 1989: 106). The philosopher writes further:

The attraction of a game, the fascination it exerts, consists precisely in the fact that the game masters the players. Even in the case of games in which one tries to perform tasks that one has set oneself, there is a risk that they will not "work", "succeed", or "succeed again", which is the attraction of the game. Whoever "tries" is in fact the one who is tried. The real subject of the ame... is not the player but instead the game itself (Gadamer 1989: 106).

Cersei Lannister, a character in the series of fantasy novels by George R. R. Martin, grasps this problem in what is, for this particular character, a strikingly aphoristic way: "When you play the game of thrones, you win or you die. There is no middle ground" (Martin 2011: 471). The protagonist addresses these words to Ned Stark, the (apparently) most formidable of her political rivals. Thanks to a well-thought out narrative focusing on the part of the author, the sympathy of readers of the first volume in the series is fixed on Ned; hence, his fall — though obliquely predicted by Cersei - may also be experienced by the reader with shock and disbelief. Only once imprisoned in the dungeon does Ned recognise that it has fallen to him to play the role of the fool. Indeed,

Since materialism would be the utopia of our time, then all that would realistically remain for us is the textual game, unending and unlimited by anything, game as far as the eye can see. Yet, who would be the subject, the lord of this game? 
throughout the whole game, this particular protagonist overestimated his powers and influence, being in essence a figurehead, moving along paths laid out for him and, finally, acquiring only such knowledge as would prove fatal to himself. And so we may well come to the conclusion that the greatest mistake Ned Stark made was that he entered the titular game at all. This does not mean, however, that the protagonist was doomed to fail. On the contrary, he could have avoided the catastrophe, or at least postponed it, either by going over to the side of the Lannisters, or by accepting the proposition made to him by Renly and pre-empting Cersei's actions. Ned acted otherwise, however; from the very beginning he engaged in the contest in such a way that his honour not suffer from it. In other words, he assumed and consistently maintained the attitude of someone who has been forced to play the game, who is not completely committed to it and participates in it only in order to gain the privilege of withdrawing himself from the game. Meanwhile, as Gadamer wrote:

Play fulfils its purpose only if the player loses himself in play. Seriousness is not merely something that calls us away from play; rather, seriousness in playing is necessary to make the play wholly play. Someone who doesn't take the game seriously is a spoilsport (Gadamer 1989: 102).

Obviously, Gadamer distinguished between the simulated world of the game and the world of our existence, superordinate to the former. Yet if Cersei were right — and the "game of thrones" were to constitute a total game, a game without borders, in which one really "wins or dies" - then, in that case, our sympathetic "spoilsport" would be driven not by any home-sickness for a familial idyll in distant Winterfell (all of this would be only his own, "private," game) but by the death drive, augmented by a complex connected with the older brother Brandon, whom Ned had to, as it were, replace in the role of lord, husband and father. In the simulacral space of a total game-for instance, the "game of thrones" - only he who "completely submits to the game" intensifies within himself the will of life.

$\vee$

I reserve the term "total game" (or "game without borders") for a contest that would no longer require apportioning to oneself a space distinct from what Gadamer calls "a world determined by the seriousness of 
purposes" (Gadamer 1989: 102). It does not require this space, since, in this particular instance, the game would turn out to be congruent with the world. If, however — as Krzysztof M. Maj argues—it is precisely thanks to immersion that "the game ceases to be a ludic contest, since it becomes reality" (Maj 2015:377), then the case of the total game would demand-no more and no less_-ideal immersion. Of course, in the real world such an ideal immersion does not occur. Maj recognises this, and so he speaks of a reduction of distance between the "world-recipient" (the reader, watcher, player) and the world of the story (storyworld), rather than a total dissolution of this distance. Thus, irrespective of the extent of the reduction, and irrespective of how much the initial value of the distance might decrease, we can safely assume that even in a far-reaching immersion, this value would, nevertheless, always remain positive, never quite reaching zero.

Maj presents immersion as "a new poetics of reception" (Maj 2015: 368) or, at least, a "style of reception" (Maj 2015: 389). But, though the status of this phenomenon seems to be strictly related to the rising role of new electronic media as vehicles of culture, it does not seem that immersion would constitute an essentially new, and formerly unknown, manner of seeing. In the dissertation The Text as World and Game, Katarzyna Prejzner was inclined to accept "immersion" (in Polish, this term was written here with a double "m") as a sort of "perspective on textuality, within which it is possible to interpret the text as a world" (Prejzner 2009: 39). The traces of an immersive mode of reception would be all the social rituals, games and forms of play that extend our experience of being in the fictional or virtual world we are entering always from the outside. Thus, immersion must be distinguished from all Romantic and Modernist efforts to transfer literature into, or repeat it in, "the real world." It is based on a movement leading in a completely opposite direction. Thus, we do not assume the role of a literary protagonist, who appears in the "real" world; on the contrary, we are arrivals "from here" who undertake the labour of exploring "another world." For this reason, the patron saints of immersion cannot be Don Quixote, Gustav or Lady Bovary. This role could, however, be filled by Dante Alighieri, Alice or perhaps captain John Carter, the hero of E. R. Burroughs' A Princess of Mars...

The problem of distance, raised by Krzysztof M. Maj, is crucial equally in this regard that it draws attention to the ambiguous relation that arises between immersion and interpretation. For the dependence between these two categories displays itself in a relation of inverse proportion: the fuller the immersion, the narrower the interpretative hori- 
zon. And though Katarzyna Prejzner mentions the "interpretation of the text as a world," it seems that it is a matter here rather of the very experience of the text as a world, but at the cost of a simultaneous overlooking of its textuality, which both authors, Prejzner and Maj, underline, independently of one another.

Michał Kłosiński approaches the matter differently. Outlining his project of a hermeneutics of video games (Kłosiński 2018), this scholar reaches for the concept of "emmersion," proposed by Piotr Kubiński. What is essential, the distancing and alienating emmersive factor would be, or at least could be, introduced intentionally, in order to upset the illusion of access to the world of the story, and in order to demonstrate its poetic organisation (Kubiński 2014; 2016). In consequence, it is precisely thanks to emmersion that a video game would fulfil the demands laid down by Gadamer for the work of art, which is a particular type of game insofar as it is intentionally open to being supplemented on the part of the recipient:

All presentation is potentially a representation for someone. That this possibility is intended is the characteristic feature of art as play. The closed world of play lets down one of its walls, as it were. A religious rite and a play in a theatre obviously do not represent in the same sense as a child playing. Their being is not exhausted by the fact that they present themselves, for at the same time they point beyond themselves to the audience which participates by watching. Play here is no longer the mere self-presentation of an ordered movement, nor mere representation in which the child playing is totally absorbed, but it is 'representing for someone.' The directedness proper to all representation comes to the fore here and is constitutive of the being of art (Gadamer 1989: 108).

If Piotr Kubiński outlined the dynamic of immersion and emmersion, then Michał Kłosiński did something different - the relation of dependence between both "forces" was grasped by him as a dialectical play, which requires an observer. This is an essential thing from a hermeneutical point of view, ${ }^{2}$ since it makes possible the transition (or, to phrase it more carefully - the transitioning) from the game to the form of art. There remains, however, another issue: namely, that art itself is understood here rather traditionally, as a work or a product. From such a perspective, a hermeneutics of video games, based on the dialectic between

2 The methodological context for the project of a "hermeneutics of video games," sketched in the work of Michał Kłosiński, are the conceptions of Hans-Georg Gadamer, and especially of Paul Ricoeur. This author does not refer to a "radical hermeneutics," under the sign of Gianni Vattimo or John D. Caputo. 
immersion and emmersion, would be a movement anti-Barthesian "in spirit"; it would be a shift from text to work.

\section{Postscript}

In an article from 2015, Maj made use of the formulation: to "imaginatively (emotionally, viscerally) inhabit a world [of a story - K. U.]" (Maj 2015: 381), borrowed from David Harman, inventor of the term storyworld, in the Routledge Encyclopedia of Narrative Theory (Herman, Jahn \& Ryan 2008). Recently, in Maj's doctoral dissertation (Maj 2018), the metaphor of "inhabiting" was replaced by "dwelling" or even "coming-to-dwell"! What is essential is that, at the end of his dissertation, Krzysztof M. Maj made reference - following Michał Kłosiński’s article "Making a dwelling of virtual worlds" (Kłosiński 2017b) — to "the experience of worldliness in Heidegger" (Maj 2018: 282). Nevertheless, still more important seems to be the grammatical change, as a result of which "dwelling in the world" was replaced by "making a dwelling of the world". This is because "making a dwelling of" gained, thereby, a relational character, while the world ceased to function independently of its "dwellers"; it no longer looked like a vacant building (ready to be occupied), but became a world because, and only because, someone made a dwelling of it. Further, the process described ceased to be a pure work of imagination, gaining, by contrast, an existential-ontic dimension. Yet all of this came at the cost of silence, on the part of the author of this dissertation, with regard to the issue that-in the fragment of Building, Dwelling, Thinking cited by him-Martin Heidegger recalls the "old bridge in Heidelberg," but not the bridge leading to, say, the Hundred Acre Wood. Let us listen to the philosopher:

\footnotetext{
If all of us now think, from where we are right here, of the old bridge in Heidelberg, this thinking toward that location is not a mere experience inside the persons present here; rather, it belongs to the nature of our thinking of that bridge that in itself thinking gets through, persists through, the distance to that location. From this spot right here, we are there at the bridge - we are by no means at some representational content in our consciousness (Heidegger 2001: 154).
}

Heidegger had in mind a place that had earlier revealed itself directly within the horizon of our experience, and was not "replanted" there from the world of the story. Nevertheless, according to Maj, this difference is completely negligible: "Instead of the metaphysical truth about 
reality what appears is the truth about world-feeling, about being in the world and about dwelling; this latter truth transgresses beyond the artificial limits [demarcations? - K. U.] between factual reality and one that is fictional, fantastic or virtual — an opposition legitimated by the modernist inheritance of metaphysical imperrealism” (Maj 2018: 282). However, there is no certainty that the problem may be reduced to "imperrealistic" prejudices. A story does not necessarily demand that we equate it with "factual reality." Its purpose is rather to make us re-think our reality from a perspective provided to us by "world-feeling," which is akin to the experience of "being transported" (in the words of Richard J. Gerrig) into the world of the narrative. Let us recall the title of Tolkien's story: The Hobbit, or There and Back Again! It is not a matter, then, of "making a dwelling in virtual worlds". It is a matter of returning from "long journeys" — while letting them alter our very selves.

We remember, of course, that for Martin Heidegger a place is an open structure: "We do not dwell because we have built, but we build and have built because we dwell, that is, because we are dwellers" (Heidegger 2001: 146). True, to dwell means among other things to rest; at least, in the view of the Heidelberg philosopher, place and path do not stand in any sort of an opposition, since the latter constitutes an extension of the former. Thus, it is no accident that the construction provided as an illustration is a bridge: "The bridge gathers to itself in its own way earth and sky, divinities and mortals" (Heidegger 2001: 151). This is important, because a bridge does not here indicate passage alone; it is also the sort of place where we gather, a way-station. For this reason, Maj next references the oikology of Tadeusz Sławek and his co-authors (Sławek et al. 2013), which describes a house as an open place, a point of departure, "from which we can depart to the world and to which we can return from that world." ${ }^{3}$ Thus, a house is not opposed to the world; on the contrary-it constitutes a portal or also a gateway; while a journey into the world allows us to look at a house from a different perspective. The lesson that's being told here is that the positions of "the house" or "the world" are transitional; while figures from a fictional or virtual world can receive us "at their place" or "at home." And this, according to Maj, is precisely the moral of an animated parabasis uploaded to YouTube, a sort of an addendum to the series of games about the witcher, Geralt. At a certain point in this film, during a feast with friends, the central figure of this fictional universe turns to face the viewer directly. Maj writes:

3 K. M. Maj, op. cit., p. 288. 
The longing of the player for the world of the game, finds its mirror reflection in the longing of the figures making a dwelling in that world-a longing, however, not so much for the player, as for a co-inhabitant, a companion during a long journey. [ . . . W World-feeling is not, then, only an act of concretisation; it is not only a manifestation of a culture of participation and it is not only a product of a xeno-encyclopedic competence. It is, above all, a manifestation of a readiness to make a home out of a fictional habitat, to which one will return and which one will miss (Maj 2018: 299).

Yet, it seems that the series of breakups and returns constitutes a somewhat too sentimental interpretation of the existential allegories offered by Heidegger and Sławek. In his essay "Making a Dwelling in Virtual Worlds," Michał Kłosiński strived, in contrast, to remain faithful to the Heideggerian category of care (of course, this is so only to the extent that we agree that all care with regard to virtual worlds is something more than a game, more than just a pretence of care). Meanwhile, let us note that "making a dwelling" suggests the somewhat provisional, casual, transient character of this activity. Since, to the extent that we live always in some specific, distinguished place, at a specific address (even if this place remains — as Heidegger would say —in motion, and the address itself has a processual character), to that extent we can make a dwelling here and there: now here, now there, a little here and a little there ... But, also from an oikological perspective, one should not necessarily tend towards a situation in which the "fictional habitat" becomes, for us, a symbolic home. Since, if it were this for anyone, it would be a "home" exclusively for the fictional characters, whereas we ourselves only make a dwelling of it, for a certain time, or from time to time.

It is also worth remembering that the animated parabasis to the series of computer games about Geralt, mentioned by Maj, is not the first supplement (or expansion?) to the "Witcher" universe. Let us recall that, in 1992, Andrzej Sapkowski wrote the story "Something Ends, Something Begins," which did not belong — but nevertheless referred — to the main series of the Witcher novels, and described the wedding of the witcher Geralt and the sorceress Yennefer. The story, published at first in the fanzine Czerwony Karzet (Red Dwarf), became, some years later, the title work in a book gathering scattered texts by the author, a decided majority of which had nothing to do with the Witcher "saga".

This work by Sapkowski cannot, of course, be treated as an epithalamium, and yet it was written-as the author informs us in the introduction — as a wedding present, a present for a couple, moreover one 
with a strong connection to the Polish fantasy fandom. True, in the story itself we do not find any devices that would intentionally disturb the illusion of autonomy of the fictional world; yet, it is necessary to note that the story's plot is focused not so much on the protagonists' wedding, as on the wedding guests, whose arrival may have been a certain surprise for Geralt and Yennefer; since "the list of guests-which was not very long-was composed by the engaged couple, while the inviting itself was to be done by Jaskier. It soon became apparent that the troubadour had lost the list, and this even before he had managed to read it. Ashamed, he did not admit to this and chose the easy way out-he invited anyone he could" (Sapkowski 2001: 173). Of course, the majority of the wedding guests are characters from the Witcher series, Geralt's companions; but there are also minor figures, with a history of only episodic appearances. The last to arrive at the Rozrog castle is the belated wedding-guest, the highwayman Vissing, known as Pow-Wow. "Geralt and Yennefer had already known Pow-Wow for a long time. Neither of them, however, had thought of inviting him. This was evidently Jaskier's job" (Sapkowski 2001: 199) Can we assume that Pow-Wow —absent from the pages of the novels - is a figure, an avatar, a symbolic and at the same time comic representation of the readers looking into the world invented by Sapkowski? Indeed, the author fulfilled the expectations of fans counting on a happy ending to the protagonists' wanderings. One way or another, Vissing was received by the newlyweds with full courtesy:

"Greetings, Vissing," said the sorceress with a smile. "It is nice that you remembered about us. Make yourself at home."

The highwayman bowed genteelly (...).

"Many years of joy and a pile of kids," he announced thunderously, "This is what I wish you, my dears. A hundred years of good fortune, what am I saying, two-hundred, for fuck's sake, two hundred. Ah, how happy I am, Geralt, and you, lady Yennefer. I always believed that you would get married; although you always argued and snapped at each other like these, if you will permit me to say, dogs. Ah, for fuck's sake, what am I saying . . .

"Greetings, Vissing, greetings," said the Witcher, pouring wine into the largest goblet standing nearby. "Drink to our health. Whence do you come? There was a rumour spread about that you were sitting in a dungeon."

"I got out," Pow-Wow drank in one gulp and sighed deeply. "I got out, after paying that, how do you say it . . . Fuck! . . . bail (Sapkowski 2001: 199).

The character's vulgar language is the smallest problem, though it does betray that Vissing, arriving at the wedding feast, has found him- 
self completely out of his element. Though he tries very hard, he is unable to behave appropriately. Yet, what is most important is the fact that Vissing has arrived uninvited and that, in general, he should not be here. He should remain beyond the stage of the fictional world, he should be "sitting in a dungeon", from which he got out after paying that, well . . bail. This interference of discourses, typical for Sapkowski, serves not only a comical effect, but also indicates the heteronomic nature of the world he created, which reveals itself as a patchwork, sewn together from various elements (one might say: each one from a different story). For this reason, there is no way to agree, without reservations, with the idea that we "make a dwelling in virtual worlds." One should, rather, speak about the fact that we only stay in them as guests, remembering at the same time the ambivalent meaning of the figure of the guest.

\section{References}

Barthes, Roland (1977). „From Work to Text.” In: Roland Barthes: Image, Music, Text. Trans. Stephen Heath. London: Fontana Press.

Berardi Franco „Bifo” (2012). The Uprising: on Poetry and Finance. Los Angeles: Semiotext(e).

Eagleton, Terry (1996). Illusions of Postmodernism. Oxford: Blackwell Publishing.

Gadamer, Hans-Georg (1989). Truth and Method. Trans. Joel Weinsheimer \& Donald G. Marshall. London: Sheed \& Ward.

Geier, Manfred (1989). „'Eden': elementy semiologii 'pozaziemskiej”, trans. Zdzisław Wawrzyniak.” In: Lem w oczach krytyki światowej, ed. Jerzy Jarzębski. Kraków: Wydawnictwo Literackie, p. 104-141.

Herman, David; Jahn, Manfred \& Ryan, Marie-Laure (2008). Routledge Encyclopedia of Narrative Theory. London-New York: Routledge

Jameson, Fredric (1991). Postmodernism, or, the Cultural Logic of Late Capitalism. Durham: Duke Univeristy Press.

Kłosiński, Michał (2017a). „Poezja jako utopijna alternatywa dla nowomowy liberalnej” In: Ekonomiczne teorie literatury. Katowice: Wydawnictwo Uniwersytetu Śląkiego.

Kłosiński, Michał (2017b). „Zamieszkując wirtualne światy”. Śląskie Studia Polonistyczne, 1 (9), p. 69-88.

Kłosiński, Michał (2018). Hermeneutyka gier wideo: interpretacja, immersja, utopia. Warszawa: Wydawnictwo IBL PAN. 
Kubiński, Piotr (2016). Gry wideo: zarys poetyki. Kraków: TAiWPN „Universitas”.

Kubiński, Piotr (2014). „Emmersja - antyiluzyjny wymiar gier wideo” Nowe Media, 4, p. 161-176.

Kuźniarz, Bartosz (2011). Goodbye Mr. Postmodernism: teorie spoteczne myślicieli późnej lewicy. Toruń: Wydawnictwo Naukowe UMK.

Lem, Stanisław (1990). Eden. Trans. Marc E. Heine. London: Andre Deutsch.

Maj, Krzysztof M. (2018). „Habitaty fikcji: narratologia transmedialna w badaniach nad światotwórstwem," doctoral dissertation supervised by Anna Łebkowska. Kraków: Jagiellonian University, Department of Polish Studies.

Maj, Krzysztof M. (2015). „Czas światoodczucia: imersja jako nowa poetyka odbioru." Teksty Drugie, 3, p. 368-394.

Martin, George R.R. (2011) Game of Thrones. London: Harper Collins.

Prejzner, Katarzyna (2009). Tekst jako świat i gra: modele narracyjności w kulturze współczesnej. Łódź: Wydawnictwo Uniwersytetu Łódzkiego.

Sapkowski, Andrzej (2001). Coś się kończy, coś się zaczyna. Warszawa: Supernowa.

Schor, Naomi (1994). „The Essentialism which is Not One: Coming to Grips with Irigaray.” In: Essential Difference, ed. Naomi Schor \& Elizabeth Weed. Bloomington: Indiana University Press.

Sławek, Tadeusz; Kunce, Aleksandra \& Kadłubek, Zbigniew (2013). Oikologia: nauka o domu. Katowice: Wydawnictwo Uniwersytetu Śląskiego.

Stone, Alison (2006). Luce Irigaray and The Philosophy of Sexual Difference. Cambridge: Cambridge University Press.

Szopa, Katarzyna (2018). Poetyka rozkwitania: różnica płciowa $w$ filozofii Luce Irigaray. Warszawa: Wydawnictwo IBL PAN.

KRZYSZTOF UNIŁOWSKI (1967-2019) - literary critic and professor of literary studies, he taught at the University of Silesia in Katowice. He wrote extensively on subjects such as the politics of literary form, history of modern literature and art, and the relationship between literary modernism and science fiction. He published nine books and received the prestigious Kazimierz Wyka Award in 2010. 
Citation: Uniłowski, Krzysztof. 2019. „Textualism, Materialism, Immersion, Interpretation”. Praktyka Teoretyczna 4(34): 13-31.

DOI: $10.14746 / \operatorname{prt} 2019.4 .2$ 